\title{
Different biochemical strategies of two Neotropical fish to cope with the impairment of nitrogen excretion during air exposure
}

V.L.P. Polez ${ }^{1}$,

G. Moraes ${ }^{1}$ and

C. Santos Neto $^{2}$
Departamentos de ${ }^{1}$ Genética e Evolução, and ${ }^{2}$ Biologia Evolutiva, Universidade Federal de São Carlos, São Carlos, SP, Brasil

\section{Correspondence}

G. Moraes

Departamento de Genética e

Evolução

Universidade Federal de São Carlos Rod. Washington Luiz, km 235

13560-905 São Carlos, SP

Brasil

E-mail: gil@power.ufscar.br

Research supported by CNPq, FAPESP and CAPES. This paper was adapted

from the thesis submitted by V.P. Polez to the Universidade Federal de São Carlos, as partial fulfillment of the requirements for a doctoral degree.

Received October 30, 2001 Accepted October 30, 2002

\begin{abstract}
The exposure of fish to air is normally expected to interfere with the nitrogen excretion process. Hoplias malabaricus and Hoplerythrinus unitaeniatus, two teleost species, display distinct behaviors in response to decreases in natural reservoir water levels, although they may employ similar biochemical strategies. To investigate this point, plasma levels of ammonia, urea, uric acid, and the two urea cycle enzymes, ornithine carbamoyl transferase (OCT) and arginase (ARG), as well as glutamine synthetase (GS) were determined for both species after exposure to air. Plasma ammonia increased gradually during exposure to air, but only H. malabaricus showed increased concentrations of urea. Plasma uric acid remained very low in both fish. Enzymatic activities (mean $\pm \mathrm{SD}, \mu \mathrm{mol} \mathrm{min}^{-1} \mathrm{~g}$ protein ${ }^{-1}$ ) of $H$. malabaricus showed significant increases $(\mathrm{P}<0.05, \mathrm{~N}=6)$ in OCT from $0.84 \pm 0.05$ to $1.42 \pm 0.03$, in ARG from $8.07 \pm 0.47$ to $9.97 \pm$ 0.53 and in GS from $1.15 \pm 0.03$ to $2.39 \pm 0.04$. The OCT and ARG enzymes remained constant in $H$. unitaeniatus $(\mathrm{N}=6)$, but GS increased from $1.49 \pm 0.02$ to $2.06 \pm 0.03$. Although these species are very closely related and share the same environment, their biochemical strategies in response to exposure to air or to increased plasma ammonia are different.
\end{abstract}

\section{Introduction}

Numerous environments that are subject to drastic climatic oscillations affect aquatic systems, eliciting a variety of responses at many biological levels (1). Periodical drastic conditions occur, particularly in some tropical freshwater systems. Fish of these systems are exposed to changes in $\mathrm{pH}$, temperature, oxygen, carbon dioxide concentration and reservoir water levels $(2,3)$. The gradual drying out during periods of drought forces fish
Key words - Hoplias malabaricus

- Hoplerythrinus unitaeniatus

- Fish

- Urea cycle enzymes

- Biochemical adaptation

- Air exposure to live in muddy waters, risking exposure to air. Fish employ a variety of strategies to minimize the effects of reduction or even the lack of effective respiratory surfaces, thus avoiding desiccation, hyperthermia and the accumulation of toxic metabolic compounds (4). The most relevant of these strategies are of a behavioral, physiological and biochemical nature. Similar species are likely to use similar strategies to cope with environmental disturbances. Nonetheless, two similar species of the family Erythrinidae-Teleostei, 
Hoplias malabaricus (trahira) and Hoplerythrinus unitaeniatus (aimara), respond differently to gradual exposure to drought $(5,6)$. Both emerged during the Jurassic period, when environmental oxygen was very scarce $(5,7)$. Although they live in lentic or stagnant waters, trahira is a water-breathing fish while aimara is a facultative one. Under extreme conditions, trahira can be found in the mud of lagoons during the dry season, becoming increasingly immobile as the water becomes hypoxic. This species, which never surfaces for air but remains immobile at the bottom of the pond, can live in muddy waters with very low concentrations of oxygen, buried in drenched silt under extremely unfavorable conditions $(5,8)$. In contrast, aimara usually slithers over land using its fins, migrating from bodies of water that are drying up to more convenient lagoons. This happens because aimara, which survives at low oxygen levels by breathing at the water's surface, possesses a highly vascularized swim bladder specially developed to deal with changes in air availability (6).

Observing the behavior of animals leads one to ponder about the mechanisms involved in their adaptation to challenging environmental changes. It is simple to imagine differentiation as something that is established gradually, over the course of time, and that is favorable - in a given environment - to the survival and reproduction of animals. Such differentiation emerges in the form of biochemical adaptations. The response to exposure to air or even to anoxia, for instance, means solving some metabolic problems, one of which is to get rid of toxic catabolites. Ammonia is a highly soluble toxic product, which is eliminated by waterliving organisms directly into the surroundings through their gills or body surface (914). Considered from this standpoint, one would expect the absence of ambient water to be as damaging as anoxia. However, biochemical mechanisms can transform ammonia, reducing its toxicity and overcoming several deleterious effects. Urea synthesis can be elected as a way to decrease ammonia concentrations, even in aquatic organisms under uncommon circumstances. This biochemical choice may be employed as a strategy, and has been reported not only for ammonia detoxification but also for acidbase and osmotic balance (15).

The urea cycle has been reported in many teleost fish $(11,12,16)$, but its role is not completely clear. Although most species do not display significant urea cycle enzyme activity, a few show a functional set (17-20). Do harsh environmental situations induce enzyme activities to prevent damage to the organism? Another point is: do closely related species respond to the same environmental stressor using different strategies? To answer these questions we selected, among a set of biochemical responses, the strategies to eliminate ammonia. Two closely related teleosts, which are usually exposed to dry seasons, were exposed to air to prevent the usual way of clearing nitrogen in fish. The two species reported on herein showed different responses, increasing the activity of enzymes definitely involved in a feasible strategy to prevent ammonia toxicity.

\section{Material and Methods}

Fish collection and maintenance

Adult $H$. malabaricus and $H$. unitaeniatus fish were collected from shallow ponds along the shores of the Mogi-Guaçu River, in the State of São Paulo, Brazil and taken to the aquaculture facilities of the National Tropical Fish Research Center (CEPTA-IBAMA) in Pirassununga, SP. The fish for all the experiments, 12 aimaras weighing $20 \pm 3 \mathrm{~g}$ (mean $\pm \mathrm{SD}$ ) and 12 trahiras weighing $60 \pm 4$ $\mathrm{g}$, were kept unfed in 500-liter boxes for 14 days before being tested. Aerated water (7.5 ppm of oxygen) was pumped from the MogiGuaçu River to the laboratory and main- 
tained constantly at $25 \pm 2^{\circ} \mathrm{C}$ throughout the experiments, at $\mathrm{pH} 7.0 \pm 0.5$. The experiments were performed in January/February as described below.

\section{Experimental design}

Twelve aimaras and twelve trahiras were transferred to four 60-liter glass aquaria (six fish per aquarium) with dark walls to minimize stress. Two aquaria, one per species, were used as control and were kept undisturbed. The water quality of the control aquaria was rigorously maintained. The experimental aquaria were gradually emptied until a very thin layer of water was left at the bottom, sufficient to keep a wet chamber. At that time, the fish were immediately and gently wrapped in wet towels to avoid hypermotility due to lack of water. They were left in this environment until the last blood puncture. Puncturing was performed individually to prevent any group effect. Blood samples were drawn from the caudal veins of both species at intervals of 15,30 , 60 and $90 \mathrm{~min}$ and an additional sample was taken from aimara at $120 \mathrm{~min}$. The additional time for aimara was based on previous experiments. The blood samples were divided into two aliquots and transferred to heparinized 2.0-ml polypropylene tubes. One aliquot was centrifuged at 9,000 $g$ for $3 \mathrm{~min}$ and the plasma stored at $-20^{\circ} \mathrm{C}$, and the other was used immediately for micro-hematocrit and $\mathrm{pH}$ determination. The fish were anesthetized with MS222 and then killed with a blow to the head and by pinching the spinal cord. The liver was excised and immediately frozen in liquid nitrogen. Liver and plasma were used for biochemical analyses.

\section{Perchloric acid plasma extract}

The plasma obtained by blood centrifugation was treated with $0.6 \mathrm{~N}$ perchloric acid $(3: 1, v / v)$ and centrifuged at $12,000 \mathrm{~g}$ for 3 min. The supernatant was used immediately to determine urea (21) and ammonia (22). Uric acid was also determined using the Folin-Denis alkaline reagent.

\section{Tissue extract}

The liver samples were homogenized in a glass vessel immersed in ice with a motordriven Teflon ${ }^{\circledR}$ pestle. The tissue/buffer ratio was 1:6 (w/v). The homogenization buffer solution consisted of $10 \mathrm{mM}$ Tris, $0.02 \mathrm{M}$ $\mathrm{Na}$ phosphate, $10 \mathrm{mM}$ glycine and $0.5 \mathrm{M}$ ethylene diamine tetraacetic acid, $\mathrm{pH} 7.0$, in glycerol $(\mathrm{v} / \mathrm{v})$. The homogenate was centrifuged at 3,000 $\mathrm{g}$ for $15 \mathrm{~min}$ at $4^{\circ} \mathrm{C}$ and the pellet was discarded. The supernatant was centrifuged at $8,000 \mathrm{~g}$ for $20 \mathrm{~min}$ at $4^{\circ} \mathrm{C}$ yielding the soluble enzyme source.

\section{Ornithine carbamoyl transferase}

The activity of ornithine carbamoyl transferase (OCT) was determined in a reaction system containing $50 \mathrm{mM}$ HEPES, $\mathrm{pH} 8.5$, $10 \mathrm{mM}$ ornithine and $10 \mathrm{mM}$ carbamoyl phosphate. The reaction medium was incubated at $25^{\circ} \mathrm{C}$ for $30 \mathrm{~min}$ and the reaction stopped by adding $70 \%$ trichloroacetic acid (TCA), after which the reaction mixtures were centrifuged at $12,000 \mathrm{~g}$ for $2 \mathrm{~min}$. Citrulline was the reaction product and was determined colorimetrically at $464 \mathrm{~nm}$, as proposed by Rahmatullah and Boyde (21).

\section{Glutamine synthetase}

Glutamine synthetase activity was measured by $\gamma$-glutamyl hydroxamate formation according to the method of Vorhaben et al. (23). The incubation mixture, containing 50 mM HEPES, pH 7.0, 60 mM glutamine, 15 $\mathrm{mM}$ hydroxylamine, $0.4 \mathrm{mM}$ ADP, $20 \mathrm{mM}$ $\mathrm{NaAsO}_{4}$ and $3 \mathrm{mM} \mathrm{MnCl} 2$, was brought to a final volume of $1.5 \mathrm{ml}$ after the addition of a suitable amount of enzyme. After $60 \mathrm{~min}$ of incubation at $25^{\circ} \mathrm{C}$, the reaction was stopped 
by adding $300 \mu \mathrm{l}$ of ferric chloride reagent. The reaction product, $\gamma$-glutamyl monohydroxamate, was measured by determining absorbance at $540 \mathrm{~nm}$ of the supernatant of the reaction mixture after centrifugation at $7,000 \mathrm{~g}$ for $1 \mathrm{~min}$ at $5^{\circ} \mathrm{C}$.

\section{Arginase}

Arginase activity was determined by measuring the formation of urea from arginine (21). The assay mixture contained 50 $\mathrm{mM}$ HEPES, $\mathrm{pH}$ 10.0, $278 \mathrm{mM}$ arginine, 10 $\mathrm{mM} \mathrm{MnCl}$ and an appropriate amount of enzyme to reach a final volume of $1.5 \mathrm{ml}$. The reaction was stopped with $70 \%$ TCA. Urea was determined by measuring absorbance at $525 \mathrm{~nm}$ of the supernatant of the reaction mixture after centrifugation at 7,000 $g$ for $1 \mathrm{~min}$ at $5^{\circ} \mathrm{C}$.

\section{Chemicals}

All chemicals were of analytical grade and were purchased from Sigma (St. Louis, MO, USA) or Merck (Darmstadt, Germany). MS222 was supplied by Sandoz (Basel, Switzerland).

\section{Statistical analysis}

Data were analyzed statistically by the

\begin{tabular}{|c|c|c|c|c|}
\hline & \multicolumn{2}{|c|}{ H. malabaricus } & \multicolumn{2}{|c|}{ H. unitaeniatus } \\
\hline & Control & Exposed & Control & Exposed \\
\hline GS & $1.15 \pm 0.03$ & $2.39 \pm 0.04^{*}$ & $1.49 \pm 0.02$ & $2.06 \pm 0.03^{*}$ \\
\hline OCT & $0.84 \pm 0.05$ & $1.42 \pm 0.03^{*}$ & $0.24 \pm 0.006$ & $0.31 \pm 0.008$ \\
\hline ARG & $8.07 \pm 0.47$ & $9.97 \pm 0.53^{*}$ & $5.36 \pm 0.54$ & $6.02 \pm 0.46$ \\
\hline Hematocrit & $21.0 \pm 0.75$ & $26.0 \pm 0.80^{*}$ & $23.0 \pm 0.76$ & $28.0 \pm 0.97^{*}$ \\
\hline Blood pH & $7.85 \pm 0.35$ & $7.60 \pm 0.43^{*}$ & $7.67 \pm 0.38$ & $7.07 \pm 0.39 *$ \\
\hline
\end{tabular}

Enzyme activities are reported as means $\pm \mathrm{SD}$ in $\mu \mathrm{mol} \mathrm{min}^{-1} \mathrm{~g}$ protein ${ }^{-1}$ for $\mathrm{N}=6$ fish . ${ }^{*} \mathrm{P}<0.05$ compared to control (Mann-Whitney test).
Mann-Whitney test, with the level of significance set at $\mathrm{P}<0.05$ for $\mathrm{N}=6$. Pearson's correlation coefficient was used for some parameters and the critical values for (r) were set at $95 \%$.

\section{Results}

Significant increases in hematocrit and reduced blood $\mathrm{pH}$ were observed in both aimara and trahira after air exposure for 120 and $90 \mathrm{~min}$, respectively (Table 1). The plasma ammonia of trahira exposed to air rose from 0.65 to $1.80 \mathrm{mmol} / \mathrm{l}$ after $60 \mathrm{~min}$, showing a trend to stabilize. However, urea concentrations increased gradually $(\mathrm{P}<0.05)$ from 0.55 to $0.90 \mathrm{mmol} / \mathrm{l}$ after $90 \mathrm{~min}$ (Figure 1A). The plasma ammonia concentration of aimara increased from 0.91 to $2.25 \mathrm{mmol} / 1$ $(\mathrm{P}<0.05)$ in the course of $120 \mathrm{~min}$, although urea remained unaltered (Figure 1B).

Glutamine synthetase activity was similar for aimara and trahira, but doubled in trahira exposed to air. A similar effect was observed for the OCT of trahira, whereas OCT activity remained constant in aimara. Both species exhibited similar arginase activities, which were kept constant even after exposure to air. The values for all the enzymatic activities are given in Table 1 and are reported as $\mu \mathrm{mol} \mathrm{min}^{-1} \mathrm{~g}$ protein ${ }^{-1}$.

\section{Discussion}

Metabolic adaptations are responsible for the survival and evolution of organisms (1). The nitrogen metabolism of fish offers a broad field of investigation of a variety of metabolic adaptations and may shed some light on the evolution of many aquatic and terrestrial vertebrates $(13,24)$. Several studies have been conducted on the urea cycle enzymes of Erythrinidae (25-29), all of which have reported on both aimara and trahira.

Aimara is usually seen over the surface of aquatic plants exposed to air. This fact, plus the potential air exchange occurring in 
the highly vascularized swim bladder, led us to determine the limiting time of air exposure for both species. The exposure of aimara and trahira to air produced different biochemical responses. The increase in hematocrit values observed in both species exposed to air or anoxia (Table 1) illustrates a common stress response in fish. The observed blood $\mathrm{pH}$ decrease is a metabolic consequence of anoxia. The absence of oxygen usually leads to fermentation and enhancement of organic acids. It is noteworthy that aimara, which has a vascularized swim bladder and can move over land, and has even been seen resting in the air on the surface of aquatic plants, showed an increase of $0.63 \mathrm{x}$ $10^{-7} \mathrm{M}\left[\mathrm{H}^{+}\right]$. In contrast, trahira, which is a restricted water-breathing fish, appears to buffer $\mathrm{H}^{+}$more efficiently since the increase of $\left[\mathrm{H}^{+}\right]$in the blood of this species under the same stressful conditions was $0.11 \times 10^{-7} \mathrm{M}$, almost six-fold lower. Comparison of the two species revealed that hepatic OCT of trahira was three times more active and, when exposed to air, this fish significantly increased this enzyme activity. These data contradict Atkinsons' proposal (15), which states that OCT should play a role in the acid-base balance by releasing $\mathrm{H}^{+}$.

The limit of blood tolerance to ammonia ranges from 0.5 to $1.0 \mathrm{mmol} / 1$ plasma in teleost fish (30). The arctic trout Salvelinus alpinus shows flaccid paralysis when plasma ammonia reaches $2.0 \mathrm{mmol} / \mathrm{l}$ (31). However, blood ammonia in the air-breathing teleost Heteropneustes fossilis exceeded 4.0 $\mathrm{mmol} / \mathrm{l}(2)$. Aimara and trahira display high blood ammonia, and exposure to air increased these values (Figure 1A,B). It can also be observed that trahira's plasma ammonia levels tended to stabilize around $1.60 \mathrm{mmol} / \mathrm{l}$ after $60 \mathrm{~min}$ of anoxia. There are no specific data on the lethal concentration of plasma ammonia for trahira, but this profile can be used to infer the limiting range. The plasma ammonia exhibited by aimara differed slightly from that for trahira. Slightly higher values were observed at the end of $120 \mathrm{~min}$, and the tendency to increase remained. The impossibility of releasing substances through the gills or skin during exposure to air should trigger strategies for minimizing ammonia toxicity. The increase of plasma urea observed in trahira plus the profile of urea cycle enzymes (Table 1) suggests that urea synthesis was an adaptive response (acclimation) to cope with the hyperammonemia resulting from exposure to air. In contrast, the constant levels of plasma urea observed in aimara suggest some distinct strategy to detoxify ammonia. Glutamine synthesis is an important step in the emergence of ureogenesis $(17,18)$ and reduction of ammonia concentration.

In fish, ammonia can be converted to glutamine via glutamine synthetase. Glutamine can be converted to glutamate to form carbamoyl phosphate and urea via urea cycle enzymes $(9,11,12)$. However, accumulation of glutamine can be considered as a choice to reduce ammonia concentration and prevent

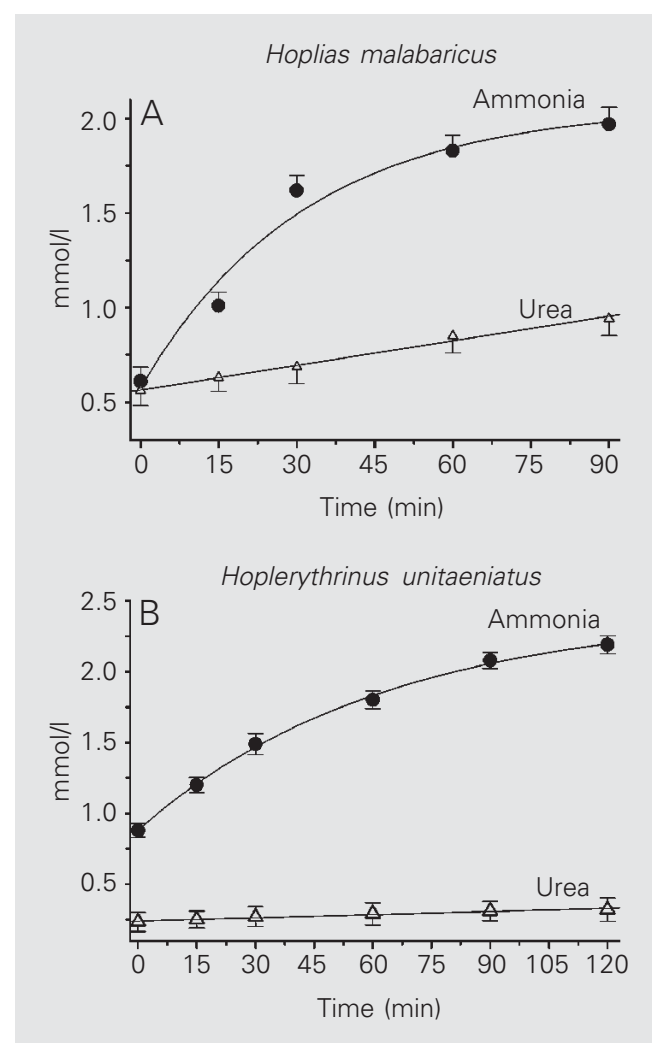

Figure 1. Plasma concentration of ammonia and urea in: $A$, Hoplias malabaricus exposed to air for 90 min and B, Hoplerythrinus unitaeniatus exposed to air for $120 \mathrm{~min}$. Twenty-four specimens were used equally distributed among four aquaria ( $N=6$ \pm SD). The animals exposed to air were maintained in a wet chamber. 
its toxicity $(9,11,32)$. Glutamine synthetase activity increased significantly in aimara exposed to air. This result, plus the picture of unchanged urea cycle enzyme activities, suggests that glutamine synthesis should be a mechanism to reduce internal ammonia in aimara.

Arginase usually responds to different types of stimuli, including changes in nutritional conditions. However, the set of responses observed in trahira strongly suggests that urea synthesis to prevent ammonia toxicity is the main reason for the increase in arginase. The increase in urea from the catabolism of uric acid is implausible, particularly considering that this is an oxidative process. Moreover, no change was detected in plasma uric acid. The unchanged urea cycle enzyme activities of aimara plus the plasma urea profile indicate that this species does not use urea synthesis as a strategy to detoxify ammonia. However, the glutamine synthetase increase suggests that the ammonia increase may play a role in inducing the synthesis of this enzyme. It is impossible to separate anoxia from the overall chain of effects caused by the stress produced by exposure to air. The stress syndrome, followed by the "general adaptation syndrome" (33), consists of several steps $(34,35)$ and cortisol release is unavoidable. The glutamine synthetase activity increases with cortisol (18), which may also explain the enhanced glutamine synthetase in both species.
In spite of the glutamine synthetase increase in aimara, the trend to an ammonia increase throughout 120 min should be responsible for the high excitability of the fish after $60 \mathrm{~min}$ of exposure to air. It should be pointed out that, despite the habits it displays, this species is apparently less resistant to internal ammonia increases. We assume, therefore, that this fish takes less than an hour to move from one body of water to another over land, thus effectively preventing plasma ammonia from reaching injurious levels. A shorter period seems sufficient to trigger the synthesis of urea cycle enzymes in trahira to prevent damage.

Trahira and aimara, two closely related teleost species living in the same environment, display different adaptive strategies to deal with the toxic effects of ammonia caused by exposure to air. Urea and glutamine synthesis were the most probable pathways involved in minimizing these metabolic injuries, which can come from water level changes. Both kinds of strategies should be chosen by many other species to cope with similar environmental harshness.

\section{Acknowledgments}

The authors thank Dr. M.A. Del Lama, Departamento de Genética e Evolução, UFSCar, for suggestions, and Alexandre E. Altran for technical support.

\section{References}

1. Hochachka PW \& Somero GN (1984). Biochemical Adaptations. Princeton University Press, Princeton, NJ, USA, 386.

2. Ratha BK, Saha N \& Chaudhury B (1995). Evolutionary significance of metabolic detoxification of ammonia to urea in an ammoniotelic freshwater teleost Heteropneustes fossilis during temporary water deprivation. ASIBE, 8: 107-117

3. Das AB \& Ratha BK (1996). Physiological adaptive mechanisms of catfish (Siluridei) to environmental changes. Aquatic Living Resources, 9: 135-143.

4. Land SC \& Berrnier NJ (1995). Estivation: mechanisms and control of metabolic suppression. In: Hochachka P \& Mommsen T (Editors), Biochemistry and Molecular Biology of Fishes. Vol. 5. Elsevier Sci- ence Publishers, Amsterdam, New York, Tokyo, 381-412.

5. Godoy MP (1975). Peixes do Brasil. Subordem Ostariophysi. Bacia do Rio Mogi-Guaçu. Vol. 3. 1st edn. Editora Franciscana, Piracicaba, SP, Brazil, 369-628.

6. Wood SC \& Lenfant C (1984). Evolution of Respiratory Process (A Comparative Approach). Vol. 1. Marcel Dekker, New York, NY, USA, 183-218.

7. Kramer DL, Lindsey CC, Moodie GEE \& Stevens ED (1978). The fishes and the aquatic environment of the central Amazon basin, with particular reference to respiratory patterns. Canadian Journal of Zoology, 56: 717-729.

8. Nelson JS (1984). Fishes of the World. John Wiley and Sons, New 
York, NY, USA, 135-136.

9. Mommsen TP \& Walsh PJ (1989). Evolution of urea synthesis in vertebrates: the piscine connection. Science, 243: 72-75.

10. Mommsen TP \& Walsh PJ (1991). Urea synthesis in fishes: evolutionary and biochemical perspectives. In: Hochachka P \& Mommsen TP (Editors), Biochemistry and Molecular Biology of Fishes. Vol. 1. Elsevier Science Publishers, Amsterdam, New York, Tokyo, 137163.

11. Mommsen TP \& Walsh PJ (1992). Biochemical and environmental perspectives on nitrogen metabolism. Experientia, 48: 583-593.

12. Wright PA (1995). Review: Nitrogen excretion: three end products, many physiological roles. Journal of Experimental Biology, 198: 273281.

13. Saha N \& Ratha BK (1998). Ureogenesis in Indian air-breathing teleosts: adaptation to environmental constraints. Comparative Biochemistry and Physiology, 120A: 195-208.

14. Leung KMY, Chu JCW \& Wu RSS (1999). Effects of body weight, water temperature and ration size on ammonia excretion by the areolated grouper (Epinephelus areolatus) and mangrove snapper (Lutjanus argentimaculatus). Aquaculture, 170: 215-227.

15. Atkinson DE (1992). Functional roles of urea synthesis in vertebrates. Physiological Zoology, 65: 243-267.

16. Felskie AK, Anderson PM \& Wright PA (1998). Expression and activity of carbamoyl phosphate synthetase III and ornithine urea cycle enzymes in various tissues of four fish species. Comparative Biochemistry and Physiology, 119B: 355-364.

17. Walsh PJ, Tucker BC \& Hopkins TE (1994). Effects of confinement/ crowding on ureogenesis in the gulf toadfish, Opsanus beta. Journal of Experimental Biology, 191: 195-206.

18. Hopkins TE, Wood CM \& Walsh PJ (1995). Interaction of cortisol and nitrogen metabolism in ureogenic gulf toadfish Opsanus beta. Journal of Experimental Biology, 198: 2229-2235.

19. Randal DJ, Wood CM, Perry SF, Bergman H, Maloiy GM, Mommsen TP \& Wright PA (1989). Urea excretion as a strategy for survival in a very alkaline environment. Nature, 337: 165-166.

20. Saha N \& Ratha BK (1994). Induction of ornithine urea cycle in a freshwater air-breathing teleost, Heteropneustes fossilis, exposed to high concentrations of ammonia chloride. Comparative Biochemistry and Physiology, 108: 315-325.

21. Rahmatullah M \& Boyde TR (1980). Improvements in the determination of urea using diacetyl monoxime: methods with and without deproteinisation. Clinica Chimica Acta, 107: 3-9.

22. Gentzkow CJ \& Masen JM (1942). An accurate method for the determination of blood urea nitrogen by direct nesslerization. Journal of Biological Chemistry, 143: 531-544.

23. Vorhaben JE, Wong L \& Campbell JW (1973). Assay for glutamine synthetase activity. Biochemical Journal, 135: 893-896.

24. Nener JC (1988). Variable and constrained features of the ornithine urea cycle. Canadian Journal of Zoology, 66: 1069-1077.

25. Polez VLP, Choudhuri JV, Souza RHS \& Moraes G (1996). Urea excretion in the erythrinidae Hoplias malabaricus (traíra), a tropical freshwater teleost fish. The Physiology of Tropical Fish Symposium Proceedings, San Francisco State University, San Francisco, CA, USA, 27-31.

26. Polez VLP, Souza RHS, Moraes G \& Altan AE (1996). Characterization of arginase activity and freshwater teleost Hoplerythrinus unitaeniatus. The Physiology of Tropical Fish Symposium Proceedings, San Francisco State University, San Francisco, CA, USA, 133-137.

27. Polez VLP, Bidinotto PM, Barbosa CC \& Moraes G (1998). Metabolic profile of the facultative air-breathing neotropical teleost fish Hoplerythrinus unitaeniatus (aimara) submitted to exercise. Special adaptations of tropical fish. The Physiology of Tropical Fish Symposium Proceedings, Baltimore, MD, USA, 1-10.

28. Polez VLP, Souza RHS \& Moraes G (1998). Nitrogenous excretion pattern of the freshwater fish Hoplerythrinus unitaeniatus (aimara): a facultative air-breathing neotropical teleost. Nitrogen production and excretion in fish. The Physiology of Tropical Fish Symposium Proceedings, Baltimore, MD, USA, 63-74.

29. Polez VLP, Monzani PS \& Moraes G (1998). Comparison of glutamine synthetase, carbamoyl phosphate synthetase and arginase from freshwater fish Hoplias malabaricus, Hoplias lacerdae and Hoplerythrinus unitaeniatus: enzyme compartmentalization. Journal of Comparative Biology, 3: 185-190.

30. Wright PA, Iwama GK \& Wood CM (1993). Ammonia and urea excretion in Lahontantan cutthroat trout (Oncorhynhus clarki henshawi) adapted to the highly alkaline Pyramid Lake (pH 9.4). Journal of Experimental Biology, 175: 153-172.

31. Lumsden JS, Wrigth PA, Derkesen J, Byrne PJ \& Ferguson HW (1993). Paralysis in farmed Artic char (Salvelinus alpinus) associated with ammonia toxicity. Veterinary Record, 133: 422-423.

32. McKenzie DJ, Piraccini G, Felskie A, Romano P, Bronzi P \& Bolis CL (1999). Effects of plasma total ammonia content and $\mathrm{pH}$ on urea excretion in Nile tilapia. Physiological and Biochemical Zoology, 72 : 116-125.

33. Pickering AD (1981). Introduction: The concept of biological stress. In: Pickering AD (Editor), Stress and Fish. Academic Press, London, UK, 1-9.

34. Colombo L, Pickering AD, Belvedere P \& Schreck CB (1990). Stress inducing factors and stress reaction in aquaculture. Aquaculture Europe 89, Business Joins Science. European Aquaculture Society. Special Publication, No. 12, Bredene, Belgium.

35. Bennet RO \& Rhodes CS (1986). Evaluation of oral administration of cortisol and metyrapone: the effects on serum cortisol in rainbow trout (Salmo gairdneri). Comparative Biochemistry and Physiology, 83A: 727-730. 